(C) Diachronica IX:2.227-238 (1992).

\title{
THE DRIFT FROM THE CODA INTO THE SYLLABLE NUCLEUS IN HAUSA*
}

\author{
PAUL NEWMAN \\ Indiana Universily
}

\section{0 . Introduction}

In historical phonology, one tends to focus on changes in sounds or in phonological features, i.e., classes of sounds. It is also necessary, however, to recognize the importance of syllable organization and structure in phonological development and the validity of internal drift as a mechanism in diachronic change. The present paper reports on historical developments in Hausa, a Chadic language of Nigeria and Niger, whereby a major component of the change was the reassignment of segments in the structure of the syllable. Specifically, without initially modifying their quality at all, some syllable-final sonorant consonants changed their status by moving from the coda into the nucleus. In keeping with what is probably a universal diachronic tendency (Pulgram 1970), closed syllables, which in Hausa have a simple coda, were thereby altered into open syllables containing a complex nucleus. ${ }^{1}$ The process can be schematized as in (1)

(1)

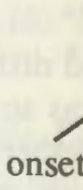

$\mathrm{x}$

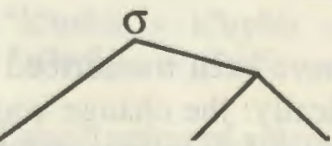

nucleus

y coda

$\mathbf{Z}$

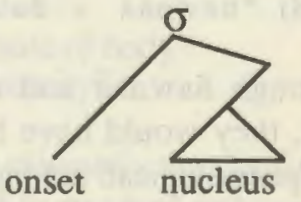

$\mathbf{X}$

y $\quad \mathrm{z}$

\footnotetext{
* This paper was presented at the Tenth International Conference on Historical Linguistics, Amsterdam, August 12-16, 1991. I am grateful to the Dean of the College of Arts and Sciences, Indiana University, for providing the necessary travel funds. Completion of the present version of the paper was supported by grants from the U.S. Department of Education (P0-17A10037) and from the National Endowment for the Humanities (RT-21236).

${ }^{1}$ Some phonologists, e.g., Goldsmith (1990:109), have declared that complex nuclei do not exist. There is ample evidence from the languages of the world that this claim is wrong.
} 
This change can be shown to reflect a general Hausa drift, which not only manifested itself a number of times in the past, but also gives evidence of being operative in the present.

I present data from four areas of Hausa as evidence for this drift into the nucleus: (1) diphthongization and monophthongization subsequent to Klingenheben's Laws and the " $r>y$ change; (2) suffixation of the linker; (3) plural morphology; and (4) formation of expressives of contempt.

\section{Diphthongization and monophthongization}

Hausa has undergone a series of well-known changes, now termed 'Klin. genheben's Laws' (Klingenheben 1927/28), whereby syllable-final coronal obstruents weakened to rolled $/$ / $/$ and syllable-final grave obstruents (velars and bilabials, the latter in some dialects only) weakened to /w/. Examples of the latter change are given in (2):2

(2) "Gakna > 6awnaa "buffalo"; "sapka > sàwka "to get down"; "zukciyaa (<"zukti + -aa "feminative suffix") > zuwcìyaa (now zuuciyaa) "heart"; "jiknaa (< jikii "body" + -naa "suffix of unknown meaning") > jiwnaa "each other"; "shipkaa > "shiwkaa "to sow"

At first, the words with the weakened consonant would have preserved the CVCCV canonical shape of the earlier forms. At some point thereafter, however, the semivowel attached itself to the nucleus and bonded with the original vowel to produce a true diphthong, e.g.,

\section{(3) *Gawnaa > Gaunaa; *sawka > sàuka}

Although 6awnaa and 6aunaa, for example, have been transcribed differently, they would have been pronounced identically: the change was structural/phonological, not phonetic. Note that the essential issue is not whether the glides should be treated segmentally as consonants (i.e., $/ y /$ and $/ w /$ ) or as vowels (i.e., /i/ and /u/); but whether they constitute independent codas as op-

2 In the Hausa examples, the hook letters 6 and $d$ indicate glottalized/implosive stops, whereas $\&$ and the digraph $t s$ are glottalized/ejective sounds. The symbol $\tilde{r}$ represents a roll or trill, which contrasts with the apical flap $r$. Double letters are used for long voweis, single letters for short vowels. Low tone and falling tone are indicated by à and $\hat{a}$, respectively: high tone is left unmarked. Tone is marked for present-day Hausa words only and not for presumed historically earlier forms. 
posed to being attached to the nucleus. ${ }^{3}$ In the case of the resulting /iv/ diphthong, which Hausa no longer has synchronically, another development ensued. Here the vowels carried the bonding in the nucleus a step further and, in accordance with general preference laws for syllable structure as described by Vennemann (1988), monophthongized into long /uv/, e.g.,

(4) *jiknaa > "jiwnaa > "jiunaa > /juunaa/ "each other" "shipkaa > "shiwkaa > "shiukaa > /shuukàa/ "to sow"

(Note: At an earlier period, the palatalized consonant before the front vowel was a conditioned variant of its corresponding alveolar [Gregersen 1967]. As a consequence of this change, palatals and alveolars in Hausa now contrast before /uu/, cf. shuukàa "to sow" with suukàa "stabbing".)

An identical process of consonant weakening, movement of a semivowel into the nucleus to form a diphthong, and then monophthongization also affected syllable-final *r's. As described by Newman (1970), non-initial " $r$ 's in early Hausa regularly weakened to $/ y /$ or $/ i /, 4$ e.g.,

(5) "suuraa > suuyàa "frying"; "kirfii > kiyfii (now kiifii) "fish"; "mar > mâi "oil"

In the case of syllables that originally contained $/ \mathrm{u} /$ before an $/ \mathrm{r} /$ coda, the weakening produced $/ \mathrm{vy} /$ sequences which, after the move into the nucleus, became /ui/ diphthongs. These, like the corresponding /iv/ diphthongs were disfavored and became eliminated by monophthongization to /ii/. 5 These changes are illustrated in (6).

(6) "k"urbii > k"uybii > k"uibii > /k"iibii/ "side of body" "g"urbii > g"uybii > g"vi6ii > /g"iibii/ "viscosity"

(Note: Labialization of velars before rounded vowels originally was (and probably still is) subphonemic in Hausa: it is not indicated in standard orthography.

${ }^{3}$ An excellent description of language specific differences in the functioning of glides is provided by Schuh (1989). The fullest treatment of the Hausa glides - which differs considerably in approach from the analysis presented here - is found in an unpublished (and never completed) paper by Parsons (n.d.).

${ }^{4}$ The change did not affect the rolled $\boldsymbol{r}$ 's, which developed much later from coronal obstruents, nor the present-day non-initial flap $d$ 's, which would appear be reflexes of an earlier */1/. ${ }^{5}$ The claim by Abubakar (1983/85) that these diphthongs still exist synchronically in Hausa is highly questionable. 
The change of /ui/ to /ii/ resulted in a formerly non-existent contrast before /ii/, cf. g*iibii "viscosity" with gii6 ii "gap".)

The changes just described affecting /uy/ sequences provide an explanation for an anomalous synchronic alternation. In Hausa, distributives of numerals are formed by reduplication, in some cases with apocopation of the final vowel of the first stem, e.g., goomà-goomà "ten each" or hur̃-hudu (< "hud-hudu) "four each". The form for "two each" in northwest dialects of Hausa is $b$ iibiyo, with unexpected labialization of the initial consonant. (In Standard Hausa, where labialization of all bilabials has been lost, the distributive surfaces as biibiyu.) The derivation of this form is actually quite straightforward when one recognizes that the underlying shape of the stem (diachronic, if not synchronic) is *buyu, with a back vowel in the first syllable, a form well supported on comparative grounds. ${ }^{6}$ The distinctive labialization affecting the initial $/ \mathrm{b} /$ results from the creation of a /ui/ diphthong by movement of the $/ y /$ into the nucleus followed by monophthongization of /ui/ to /ii/. The change of *buyu to biyu simply reflects the assimilatory change of $/ \mathrm{u} / \mathrm{to} / \mathrm{i} /$ in the environment of $/ y /$. The derivation is shown in (7):

\section{(7) *buyu "two" $\Rightarrow$ "buy-buyu $\rightarrow$ "b"uibuyu $\rightarrow$ b"iibiyu "two each"}

It should be pointed out that the general move toward monophthongization that eliminated the /iv/ and /ui/ diphthongs is now turning the present-day /ai/ diphthong into $/ e e /, 7$ although so far in a sporadic fashion, e.g.,

(8) leemàa < and = laimàa "umbrella"; deedee < and = daidai "correctly"; koosee (without palatalization!) < and = koosai "fried beancake"

There are also examples of the change from /au/ to /oo/, illustrated in (9), although this is less common, e.g.,

(9) loomàa < and = laumàa "mouthful" wàatòo < and = wàatàu "that is to say";

dookii "horse" < "daukii < "dawkii (cf. the internal plural dawaakii)

\footnotetext{
${ }^{6}$ Cognate forms with a back vowel such as bolu (in Maha) and vul (in Sura) are common in the West A subbranch of Chadic to which Hausa belongs.

${ }^{7}$ For a phonetic description, see Lindau-Webb (1985); for a non-standard phonological proposal, see Newman \& Salim (1981).
} 


\section{Suffixation of the linker}

The evidence that surface diphthongs have come to be attached to the nucleus, rather than occupying both nucleus and coda slots, is provided by their behavior when a genitive linker is attached. The general rule in Hausa is that if the linker (which has the bound form $-\tilde{r}$ with feminine and $-n$ with masculine and plural nouns) is added to a word ending in an open syllable, the linker attaches itself to the empty coda slot. The nucleus is then shortened, if necessary, in accordance with regular overload rules that affect overheavy syllables (Newman 1972), e.g.,

(10) *zanèe-n-tà ("cloth-of-her") $\rightarrow$ zanèntà "her cloth"; "raanaa-r̃ kàasuwaa ("day-of market") $\rightarrow$ raanar̃ kàasuwaa "market day"

If the word ends in a closed syllable, i.e., if the coda is already occupied by a syllable-final consonant, an epenthetic vowel is inserted to create a new coda slot for the linker to occupy, e.g.,

(11) "teebữ -n-sà ("table-of-his") $\rightarrow$ teeburininsà "his table": "Raamùs-n Muusaa ("dictionary-of Musa") $\rightarrow$ Raamùsun Muusaa "Musa's dictionary"

As indicated above, although diphthongs most often derive historically from VC sequences, (e.g., mâi "oil" < "may < "mar), they have since migrated into the nucleus, thereby leaving the coda empty. Thus the linker occupies the available free slot rather than requiring an epenthetic vowel. The second element of the diphthong is then clipped as is required of long monophthongs, e.g.,

(12) "kìbau-n-sà ("arrows-of-his") $\rightarrow$ kìbansà "his arrows";

*mâi-n shaanuu ("oil-of cows") $\rightarrow$ mân shaanuu "butter"

\section{Plural morphology}

In Hausa the specific plural pattern used with particular nouns depends to a great extent on the syllabic shape and tone of the singular (see Newman 1986, 1987). CVCV nouns with all high tones and a long vowel in the first syllable add an -aayee suffix with an associated HLH tone pattern, e.g.,

(13) zoomoo + -aayee $\rightarrow$ zoomàayee "hares"; suunaa + -aayee $\rightarrow$ suunàayee "names" 
CVCCV nouns with all high tones employ an affix -aa...ee, which is often referred to as an 'internal -aa-plural'. This affix is also accompanied by the HLH tone pattern, e.g.,
(14) maskoo + -aa...ee $\rightarrow$ masàakee "large hammer"; gulbii + -aa...ee $\rightarrow$ gulàabee "streams"

Since diphthongs in Hausa constitute complex nuclei, words with a diphthong in the first syllable pattern with the corresponding long vowel words rather than those whose first syllable contains a consonantal coda, e.g.,

(15) bauree + -aayee $\rightarrow$ bauràayee "fig trees" (not *bawree + -aa...ee $\rightarrow$ "bawàaree); maisoo + -aayee $\rightarrow$ maisàayee "disused farms" (not *maysoo + -aa...ee $\rightarrow$ *mayàashee); baunaa + -ayee $\rightarrow$ 6aunàayee "buffaloes"

The word baunaa has an alternative plural bakàanee reflecting the root * Gaknaa, which existed in the language before the operation of Klingenheben's laws. What one does not get is *6awaanee, which would be the expected plural if the $/ w /$ resulting from the ${ }^{*} k>/ w /$ change had remained in the coda.

Given the interpretation of /ai/ and /au/ as complex vocalic nuclei, their behavior in plurals is as expected. What makes plural formation particularly interesting is that it provides evidence for the shift of another consonant into the nucleus, namely / $\mathbf{n} /$. It has been known for some time that singular nouns of the form CVnCV and an all high tone pattern do not use the internal -aa-plural, but rather employ the -aayee suffix, e.g.,

(16) kundii "notebook", pl. kundàayee (not *kunàadee); guntuu "stub", pl. guntàayee (not "gunàacee); g"ankii "roan antelope", pl. g"ankàayee (not "g"anàakee)

In Newman \& Salim (1981), we tried to explain this by proposing that the final /n/ was in effect an underlying nasalized vowel. 'Nasal diphthongs', as we called them, would then have been expected to behave in plural formation just like oral diphthongs. A much simpler explanation, which does less violence to the phonetic facts and our traditional ways of looking at Hausa phonology, is just to say that Hausa nasals are too weak to stand as codas on their own (especially in word medial position), and thus are drawn into the nucleus. The reason the plural of kundii is not *kunaadee is not because / $\mathbf{n} /$ segmentally is a 
vowel - presumably it is still a consonant of sorts - but because the $/ \mathrm{n} /$ is in the nucleus, not in the coda. This is illustrated in the diagram in (17), where kundii with the syllable-final $/ \mathrm{n} /$ is contrasted with maskoo "hammer" with a syllable-final $/ \mathrm{s} /$.
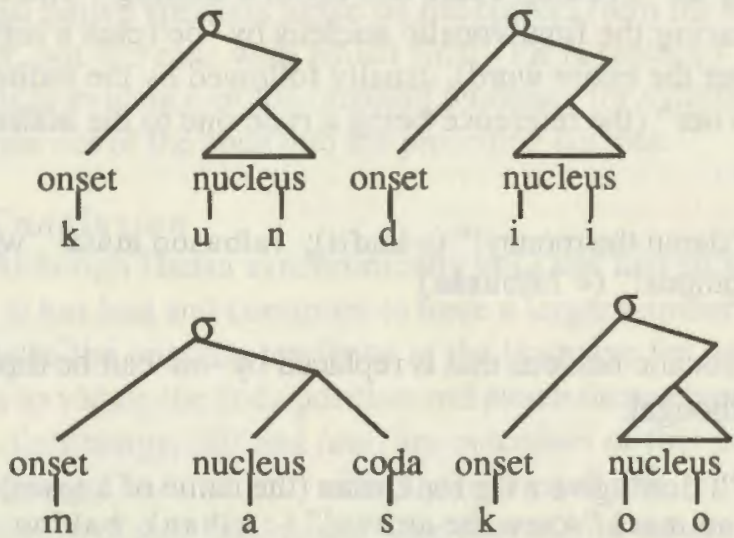

The weakness of $/ \mathrm{n} /$ in Standard Hausa when occurring at the end of a syllable within a word is shown by the fact that in that environment, it is always homorganic. Whereas Hausa has two distinct nasals in syllable initial position, /n/ and $/ \mathrm{m} /$, the weak syllable-final nasal has no position features: $/ \mathrm{n} /$ and $/ \mathrm{m} /$ have merged into a single nasal $/ \mathrm{N} /$, which takes its position from the following consonant, e.g.,

(18) Kàzàntaa "fïlthiness" ( < Ràzaamii "filthy"); mutuncìi "humanity" (< mùtûm "man"); sarkim Bauci "the chief of Bauci" (< sarkii-n); ran kìaamàa "judgment day" ( $<$ ran contracted form of raanấ "day of")

Interestingly, in the northwest Hausa dialects where syllable-final $/ \mathrm{m} /$ 's remain distinct from $/ \mathrm{n} /$ and do not assimilate, the nasals continue to occupy the coda position and thus are available for various internal -aa- plurals, ${ }^{8}$ e.g.,

${ }^{8}$ Another way to look at it is to say that the reason the $/ \mathrm{m} /$ still has its position features and thus is identifiable as such is because it has not yet been drawn into the nucleus. Viewed this 
(19) g"amkii "roan antelope", pl. g"àmàkkai [NW Hausa] (cf. (16) above)

\section{Expressives of contempt}

Hausa has an exclamatory construction that expresses derision or contempt regarding the person or thing mentioned (Newman 1988). For example building on the word sulèe "shilling", one could say suloo mata", which would translate approximately as, "I couldn't care less about a shilling". The expression is formed by replacing the final vocalic nucleus by -oo (plus a high tone pattern that extends over the entire word), usually followed by the indirect object pronoun matà "to her" (the reference being a rude one to the addressee's mother). For example,

(20) kưoo matà "damn the money!" (< kưdii); ?albasoo matà "who cares about the onions!" ( $<$ ?àlbasàa)

As shown in (21), the vocalic nucleus that is replaced by -oo can be diphthon $\mathrm{gal}$ as well as monophthongal.

(21) Gusoo matà "I don't give a fig for Gusau (the name of a town)!" (< Gùsau); kiboo matà "screw the arrows!" (< kibau); bak"oo matà "who cares about 7!" (< bak"ài); tuddoo matà "damn the hills!" (< tùddai)

If a word end in a consonantal coda, the -00 (with the associated tone pattern) is simply attached as is, e.g., 9

(22) teebur̃oo matà "don't bug me about the table!" (< teebur) ; Jaamusoo matà "so what about Germany!" ( $<$ Jaamùs); maalamoo matà "the hell with the teacher!" (< maalàm)

Interestingly, final /n/'s, which, like other final consonants, are normally found in loanwords or proper nouns, do not pattern with the other consonants, Although there are a few exceptions where they do behave like consonantal codas, e.g., Japanoo matà (< Jàpân) "so what about Japan!", in most cases,

way, the move into the nucleus would be the cause of the nasal weakening rather than its consequence.

9 With vowel-final monosyllabic words, the -00 is also additive rather than replacive, an epenthetic glide being inserted where necessary, e.g., jaswoo < jaa "red", ciyoo < ci "eat", mayoo < mâi "oil", sawoo < sau "foot". (Note that the initial vowel of sawoo is short, showing that the expressive is built directly on the root sav and not on the longer variant saa wuv, which is found in northwest dialects.) 
the $/ \mathrm{n} /$ seems to have moved into the nucleus, so that the final $-\mathrm{Vn}$ is replaced by -oo just like an oral diphthong, e.g.,

(23) talaatoo matà (not *talaatinoo matâ) "What's thirty to me!" (< tàlàatin); Baadoo matà "Ibadan, big deal!" (< Bàadùn); Pambuloo matà "Don't bother me about the envelope!" (< ?ambùlàn) $)^{10}$

Not all native speakers agree on the correct form for these expressives of contempt, but the ease with which final $-V_{n}$ is replaced by -oo in modern loanwords is evidence of the ongoing tendency for syllable final $/ \mathrm{n} /$ 's in Hausa to migrate out of the coda into the preceding nucleus.

\section{Conclusion}

Although Hausa synchronically only has two surface diphthongs, /ai/ and lau/, it has had and continues to have a larger number of complex nuclei. This is due to the ongoing tendency in the language for weak syllable-final consonants to vacate the coda position and attach themselves to the nucleus. The current diphthongs, /ai/ and /au/, are outcomes of this process, as are the former diphthongs, /iu/ and / $\mathrm{i} /$ /, which have bonded into / $\mathrm{uv} /$ and /ii/ respectively. In addition, syllable-final nasals have moved into the nucleus in the past and continue to move into the nucleus as part of an ongoing process, thereby producing complex nuclei that function very much like vocalic diphthongs. As is typical of historical change in progress, the unsettled state of syllable-final nasals is reflected in lexically specific and dialectal variation. It is not clear how many times and when different elements in Hausa have moved from the coda into the nucleus; but the persistence and overall direction of the drift are clear. Since there is no reason to believe that the force behind this drift is spent, it seems likely that historical linguists working on Hausa a generation from now will have additional cases of this phenomenon to comment on.

\section{Author's address:}

\section{Paul Newman}

Inst. for the Study of Nigerian Languages \& Cultures Indiana University

BLOOMINGTON, IN 47405, U. S. A.

${ }^{10}$ Evidence that word-final $/ \mathrm{n} /$ is attached to the nucleus and thus is subject to replacement when a suffix is added is also provided by some plural forms, e.g., tangaran "chinaware, dish", pl. tangaràayee. 


\section{REFERENCES}

Abubakar, Abdulhamid. 1983/85. "Another Look at Hausa Diphthongs". Harsunan Nijeriya 13.1-20.

Goldsmith, John. 1990. Autosegmental and Metrical Phonology. Oxford: Basil Blackwell.

Gregersen, Edgar A. 1967. "The Palatal Consonants in Hausa". Journal of African Languages 6.170-184

Klingenheben, August. 1927/28. "Die Silbenauslautgesetze des Hausa". Zeitschrift für Eingeborenensprachen 18.272-297.

Lindau-Webb, Mona. 1985. "Hausa Vowels and Diphthongs". Studies in African Linguistics 16.161-182.

Newman, Paul. 1970. "Historical Sound Laws in Hausa and in Dera (Kanakuru)". Journal of West African Languages 7.39-51.

...-.... 1972. "Syllable Weight as a Phonological Variable". Studies in African Linguistics 3.301-323.

-..-. 1986. "Tone and Affixation in Hausa". Studies in African Linguistics $17.249-267$.

-..-. 1987. "Hausa and the Chadic Languages". The World's Major Languages ed. by Bernard Comrie, 705-723. London: Croom Helm.

-..... 1988. "O Shush! An Exclamatory Construction in Hausa". Studies in Hausa Language and Linguistics: In Honour of F. W. Parsons ed. by Graham Furniss \& Philip J. Jaggar, 89-98. London: Kegan Paul International.

Newman, Paul, \& Bello Ahmad Salim. 1981. "Hausa Diphthongs". Lingua 55.101-121.

Parsons, F. W. n.d. [ca. 1980] "The Semivowels of Hausa". Unpublished MS, School of Oriental and African Studies, Univ. of London.

Pulgram, Ernst. 1970. Syllable, Word, Nexus, Cursus. The Hague: Mouton. Schuh, Russell G. 1989. "Long Vowels and Diphthongs in Miya and Hausa". Current Approaches to African Linguistics (vol. 5) ed. by Paul Newman \& Robert D. Botne, 35-43. Dordrecht: Foris.

Vennemann, Theo. 1988. Preference Laws for Syllable Structure and the Explanation of Sound Change. Berlin: Mouton de Gruyter.

\section{SUMMARY}

This paper illustrates the importance of syllable organization in phonological development and the validity of drift as a factor in diachronic change. At an earlier period, word medial CVC syllables, with the second $\mathrm{C}$ belonging to the coda, were quite common in Hausa. As a result of well-known sound laws, many of the syllable-final consonants underwent weakening, e.g., " $k>w{ }^{*} t$ $>\tilde{r},{ }^{*} r>y_{1}{ }^{*} m>N$ (a homorganic nasal). Subsequently, the erstwhile syl- 
lable-final consonants broke away from the coda and attached themselves to the nucleus. Thus, $/ y /$ and $/ w /$ codas, for example, have moved into the nucleus to form true /ai/ and /au/diphthongs. This same process also produced */ui/ and */iu/diphthongs, which subsequently simplified into /ii/ and /uu/ respectively. The drift into the nucleus also affected nasal consonants, so that $\mathrm{CVn}$ syllables often pattern with syllables containing a diphthong or a long vowel rather than with CVC syllables. Data from four areas of Hausa are presented to illustrate the move from the coda into the nucleus: (1) diphthongization and monophthongization subsequent to consonant lenition in the coda; (2) suffixation of the linker; (3) plural morphology; and (4) formation of expressives of contempt. The change is shown to reflect a general Hausa drift, which not only manifested itself a number of times in the past, but also gives evidence of being operative in the present.

\section{RÉSUMÉ}

L'article montre l'importance de l'organisation syllabique dans le développement phonologique et la validité du 'drift' comme facteur dans le changement diachronique. En hausa, anciennement les syllabes de structure CVC à l'intérieur du mot, dont la seconde $\mathrm{C}$ appartient à la coda, étaient assez répandues. Par la suite de lois phonétiques bien connues, de nombreuses consonnes furent affaiblies à la fin de syllabe, e.g., ${ }^{*} \boldsymbol{k}>w_{,}{ }^{*} t>\tilde{r},{ }^{*} r>y,{ }^{*} m>N$ (nasale homorganique). Plus tard, les consonnes primitivement finales de syllabe se détachèrent de la coda et se rattachèrent au nucleus. Ainsi, les codas $/ y /$ et $/ w /$, par exemple, se sont mues dans le nucleus pour former des vraies diphtongues /ai/ et /au/. Le même procès a également produit des diphtongues */ui/ et */iu/, qui par la suite ont été simplifiées en /ii/ and /uv/ respectivement. Ce 'drift' dans le nucleus affecta également les consonnes nasales, de sorte que les syllabes CVn s'alignent souvent sur des syllabes qui contiennent une diphtongue ou une voyelle longue plutôt que sur des syllabes CVC. L'article présente des donnés tirées de quatre secteurs du hausa pour illustrer le mouvement de la coda dans le nucleus: 10 diphtongaison et monophtongaison par suite d'une lénition consonnantique dans la coda; $2^{\circ}$ suffixation du connecteur; $3^{\circ}$ morphologie du pluriel, et $4^{\circ}$ la formation des expressions du mépris. Dans tous ces cas le changement reflète un reflet une tendance générale en hausa, qui non seulent se manifesta plusieurs fois dans le passé, mais qui continue à se manifester au actuellement. 


\section{ZUSAMMENFASSUNG}

Der Aufsatz illustriert die Wichtigkeit der silbischen Organisation in der phonologischen Entwicklung und den Wert von 'drift' als einen Faktor in der Sprachgeschichte. Zu einem früheren Zeitpunkt waren im Hausa Silben der CVC-Struktur im Wortinnern, wobei das zweite $\mathrm{C}$ zur Coda gehörte, weit verbreitet. Als Ergebnis gut bekannter Lautgesetze unterlagen viele dieser endsilbigen Konsonanten einer Abschwächung, z.B. ${ }^{*} k>w,{ }^{*} t>\tilde{f},{ }^{*} r>y_{1}{ }^{*} m$ $>N$ (ein homorganer Nasal). Später lösten sich die vordem endsilbigen Konsonanten von der Coda und schlossen sich dem Nukleus an. So bewegten sich beispielsweise /y/-und/w/-Codas in den Nukleus um echte /ai/- und /au/Diphthonge zu bilden. Der gleiche Prozess produzierte ebenfalls */ui- $/$ und */iu/-Diphthonge, die sich danach zu /ii/ bzw. /uu/ vereinfachten. Dieser 'drift' in den Nukleus ergriff ebenfalls nasale Konsonaten, so daß CVn-Silben oftmals dem Muster der Silben folgen, die einen Diphthong oder einen langen Vokal enthalten, anstelle dem der CVC-Silbenstruktur. Es werden hier Daten aus vier Bereichen des Hausa gezeigt, die diese Bewegung von der Coda in den Nukleus illustrieren: 1) Diphthongisierung und Monophthongisierung als Folge einer Konsonantenabschwächung (Lenition) in der Coda; 2) Suffixierung des Bindegliedes; (3) Pluralbildung und (4) Bildung von Ausdrücken der Verachtung. In allen Fällen weist der Wandel eine allgemeine Tendenz im Hausa auf, die sich nicht nur mehrere Male in der Vergangenheit zeigte, sondern allen Anschein hat, auch noch in der Gegenwart zu wirken. 